\title{
Developing Mobile Learning Media Integrated of Problem Based Learning in Chemical Equilibrium Materials at Unimed Chemical Education Study Program
}

\author{
Nora Santi \\ Postgraduate of Chemistry Education \\ Universitas Negeri Medan \\ Medan, North Sumatera, Indonesia \\ norasanti.ns@gmail.com
}

\author{
Zainuddin Muchtar \\ Department of Chemistry \\ Universitas Negeri Medan, 20221 \\ Medan, North Sumatera, Indonesia
}

\author{
Ajat Sudrajat \\ Departement of Chemistry \\ Universitas Negeri Medan, 20221 \\ Medan, North Sumatera, Indonesia
}

\begin{abstract}
This study aimed to understand level of feasibility of learning media mobile learning for special topic of chemical equilibrium; and to know the differences of the improvement learning outcomes of students is problem based learning in learning chemical equilibrium studied by using media of Mobile Learning developed with power -point. It used $R$ \& D method (Development Research) with model ADDIE. Sample selection using purposive sampling technique. The population in this study were college student S-1 of semester II of chemistry education study program taking elementary chemistry courses even semester 2018/2019 at State University of Medan. The sample in this research are two classes in the basic course chemistry of FMIPA UNIMED department semester 2 which have 25 students for each class. The research instruments are motivation questionnaire and objective test. Data were analyzed using descriptive method and statistical analysis with independent sample t-test. The result showed that: (1) the developed learning media of Mobile Learning was categorized with feasible to used but still needs to be revised and developed, (2) there was the difference improvement learning outcomes of students ( $\mathrm{N}$-gain of students) for special topic of chemical equilibrium that learned using media of Mobile Learning which had been developed in experimental class I was found higher than that in experimental class IIwith power-point media $(74 \%>63 \%)$.
\end{abstract}

Keywords-Mobile Learning, Problem Based Learning (PBL), Chemical Equilibrium, Students Achievement) Introduction

\section{INTRODUCTION}

The development of information, communication and technologies from year to year has increased and provided a lifestyle change and human viewpoints from various aspects, both aspects of politics, business, health and education. The presence of technology in educational field gives enormous benefit in enhancing the quality of education. Technology can be used as one of sources and learning media which is effective and capable of changing a conventional learning into a modern one so that the learning process is no longer centered on the educator (Teacher-Centered), but it is subjected to the learners (student-centered) [1]
The rapid development of science and technology has a major influence in improving the quality of teachers in Indonesia. Efforts to improve the quality of teachers can be done with innovations in learning such as the development of learning methods, provision of teaching materials, procurement of laboratory equipments, improvement of teacher quality and development of learning media [2]. Learning media which have been applied in learning is expected to streamline the learning process, to achieve the learning objectives in order to improve students learning achievement, as well as to motivate them towards the subject matter [3].

The development of learning media, both used for formal and informal learning, is undertaken based on the main reference, the current applicable curriculum. In addition the ease of use, interesting features, and the usefulness should also be noticed. This corresponds to what is conveyed by the Mulyanta [4] in that the criterion of a good learning media ideally has 4 main factors, namely: the relevance, simplicity, interesting features, and also benefit.

Learning media has now become a necessity in the learning process. The use of instructional media can overcome common obstacles that often occur in the learning process, such as limited hours in class, boredom in the learning process, and the complexity of delivering abstract material [5]. The existing chemistry learning process needs to be improved and designed in such a way with learning conditions that have attraction and fun so that students are more excited, passionate, motivated to learn chemistry. If students have felt their interest in chemistry, then one day they can improve the quality of logical, critical, analytical and cognitive thinking [6].

One important material taught in chemistry learning is Chemical Equilibrium. Chemical Equilibrium material is quite difficult to understand because it involves reasoning so that to understand this is certainly not enough just by reading books, students must practice more to improve understanding. The provision of interactive learning media in the form of mobile learning can help students to practice working on Chemical 
Equilibrium related questions anywhere and anytime, even without being accompanied by the teacher.

An interview with one lecturer basic chemistry courses obtained information that the chemistry learning that occurs in this class still uses conventional methods and sometimes uses discussion methods. The media used by the lecturer is power point, videos from the internet, and books.

Innovation is needed to realize the hope of improving learning outcomes in the teaching and learning process. One solution to overcome these problems is by developinglearning media, namely mobile learning. The existence of renewal is to develop learning media that is interesting, feasible and effective by combining between Android-based worksheet and inside it contains chemical material. Learning media in the form of worksheet that are educational on mobile phone (android) is effective as a learning medium that can help students' understanding so that it can improve learning outcomes. Another advantage is the active participation of students to learn [7] [8].

The benefit of mobile are: 1. Relatively inexpensive opportunities, as the cost of mobile devices are significantly less than PCs and laptops 2. Multimedia content delivery and creation options 3. Continuous and situated learning support 4. Decrease in training costs 5. Potentially a more rewarding learning experience 6. Improving levels of literacy, numeracy and participation in education amongst young adults [9].

\section{METHOD}

The research was conducted on April 2019. The population in this study were college student S-1 of semester II of chemistry education study program taking elementary chemistry courses even semester 2018/2019 at State University of Medan. The samples were class X A 1 and X D where both of classes were elected using technique of purposive sampling. 25 students of class X A were taught using power-point media, and 25 students of class X D using mobile learning media which is had been developed (Experiment II). It was research development with a model of ADDIE (Analysis, Design, Development, Implementation and Evaluation). These steps include: (1) Analysis (analyzing the need for new development, analyzing the feasibility and requirements of developing new media), (2) Design (designing and preparing initial product or product design), (3) Development (realizing product design ), (4) Implementation (use of new learning media that has been developed in real situations in the classroom), (5) Evaluation (measuring the final competence of instructional media). The research instruments used to collect data are questionnaires and objective tests. Stages of development of learning media chemistry by using Easy Sketch is illustrated in Figure 1

\section{A. Research Instrument}

The research used methods by test and non-test as instrument. Non-test instrument that have been used was SNPT questionnaire integrated with mobile learning media. While the test instrument was multiple choice questions which consisted of 25 questions concerned about chemical equilibrium, and it was validated before it used. Questions test were arranged in accordance with Bloom Taxonomy. Data were completely collected after the answer sheets have been assessed and scored.

\section{B. Data Analysis}

There are several steps for data analysis of this study: (1) tabulating the data obtained from $\mathrm{N}$-gain for students' pretest of class of experiment I and experiment II; (2) tabulating the data gained from $\mathrm{N}$-gain post-test for class of experiment I and experiment II; (3) testing for data normality; (4) testing the data homogeneity; and (5) testing the hypothesis using independent sample $\mathrm{T}$ - test with program SPSS 21 for Windows by significant value of 0.05 where $\mathrm{Ha}$ will be accepted and $\mathrm{H} 0$ will be rejected if $-\mathrm{t}$ count $<-\mathrm{t}$ table or $\mathrm{t}$ count $>\mathrm{t}$ table for receiving alternative hypothesis [10].

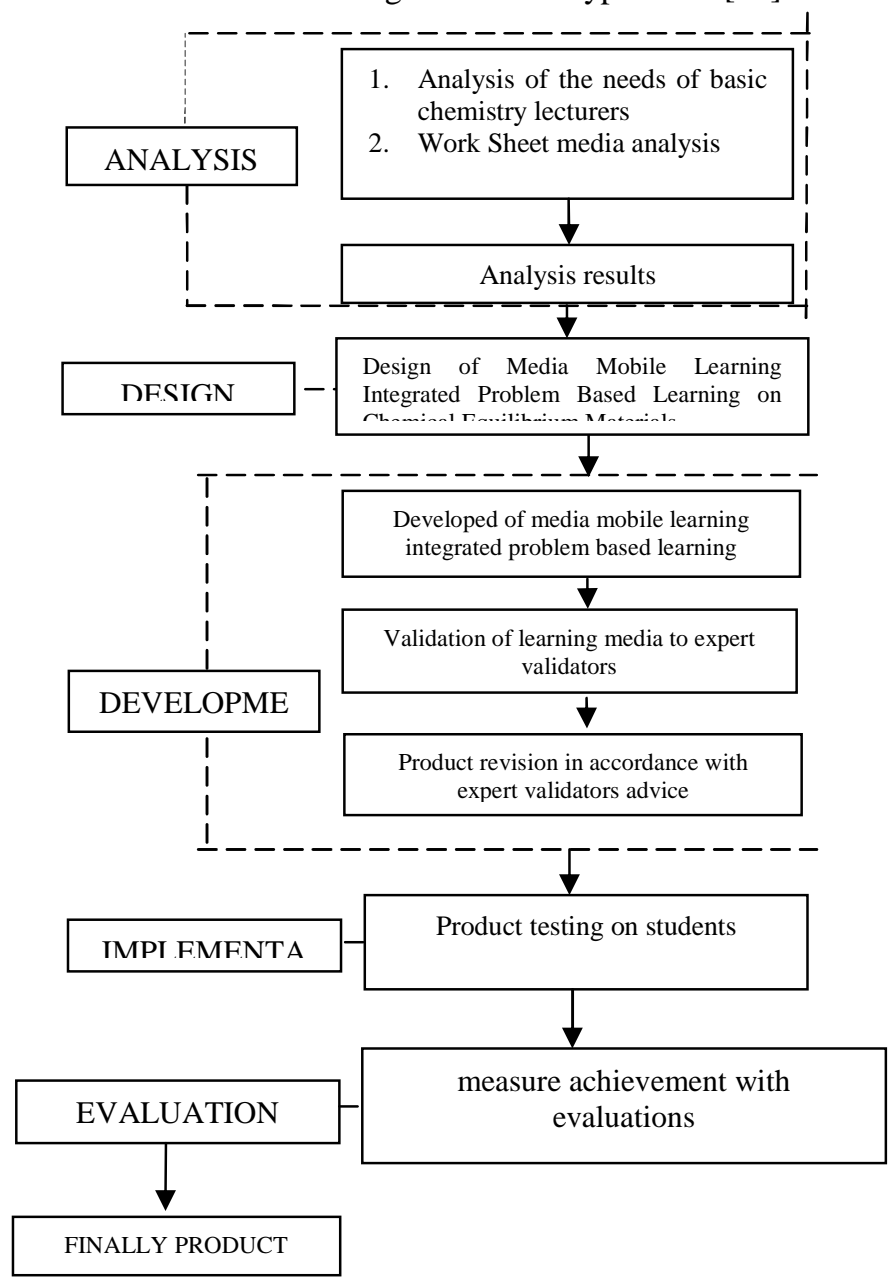

Fig. 1. Research design 


\section{RESULT}

This study aims to develop an integrated mobile learning media model of problem based learning in basic chemistry learning to improve student learning outcomes and student motivation. This learning media was developed using model of ADDIE. It has 5 stages, namely analysis, design, development, implementation and evaluation.

\section{A. Students' Achievement}

Based on student learning outcomes data obtained in the study and after the tabulated data obtained the average and standard deviations from the pretest and posttest data both from the experiment I class and experiment I like table I:

TABLE I. AVERAGE AND STANDARD DEVIATION

\begin{tabular}{lllcc}
\hline \multicolumn{1}{c}{ Group } & \multicolumn{2}{c}{$\begin{array}{c}\text { Average value } \\
\text { deviation }\end{array}$} & \multicolumn{2}{c}{ Standard } \\
\cline { 2 - 5 } & $\begin{array}{l}\text { Pre-test } \\
\text { test }\end{array}$ & Post-test & Pre-test & Post- \\
\hline Experiment I & 46,08 & 85,12 & 9,74 & 8,45 \\
\hline Experiment II & 52,16 & 81,92 & 8,44 & 8,50 \\
\hline
\end{tabular}

\section{B. Improved Students' Achievement}

Improved student learning outcomes (student N-gain) can be seen from the difference in the average value of pretest and posttest. The average results of the pretest and posttest values in Table 2.

TABLE 2. DIFFERENCE IN GAIN

Classes \% Gain Difference in Gain Explanation

\begin{tabular}{|c|c|c|c|}
\hline Experiment I & $74 \%$ & & Medium \\
\hline Experiment II & $63 \%$ & & Medium \\
\hline
\end{tabular}

Based on the table it can be concluded that the increase in learning outcomes in Experiments I group is greater than the increase in learning outcomes in Experiment II group.

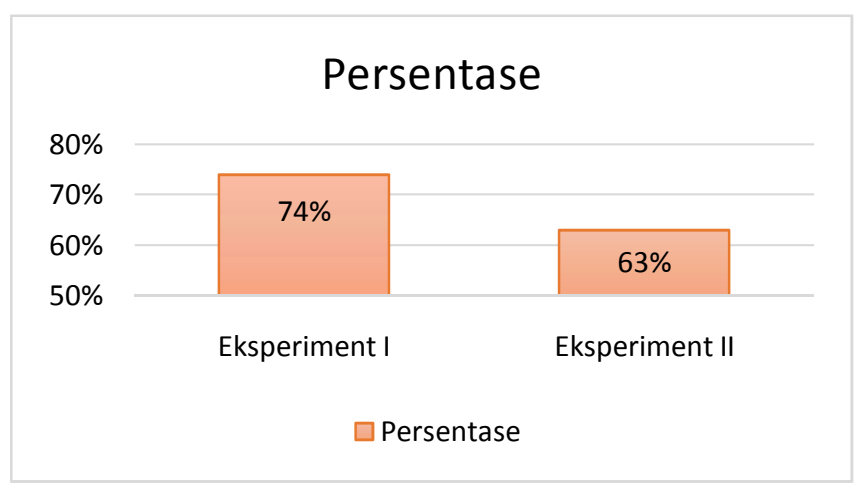

Fig. 2. Research Data Graph
Based on the picture above, it can be concluded that the percent increase in learning outcomes of experimental chemistry II that uses the integrated Power Point media problem based learning model is $63 \%$ lower than that of the experimental class I which implements an integrated mobile learning media PBL model that is $74 \%$.

\section{Hypothesis Test}

From the distribution table of pre-test and post-test learning outcomes both samples are normally distributed and homogeneous data, then hypothesis test is performed. This test was proposed to observe the successfulness of media in chemistry learning developed to enhance students' achievement as their conceptual skills examined using independent sample T-test. The result will be presented in Table 3.

\section{TABLE 3. HYPOTHESIS TEST}

\begin{tabular}{lccc}
\hline \multicolumn{1}{c}{ Hypothesis } & $\begin{array}{c}\text { Sig. (2- } \\
\text { tailed) }\end{array}$ & $\boldsymbol{\alpha}$ & Conclussion \\
\hline $\begin{array}{l}\text { There is a difference in } \\
\text { the increase in student }\end{array}$ & & & \\
learning outcomes that & & & \\
are taught using mobile & & & \\
learning media with & & & \\
PowerPoint accepted \\
integrated PBL learning \\
models on chemical \\
equilibrium learning.
\end{tabular}

Based on table 3 the hypothesis test criteria are met, meaning that $\mathrm{Ha}$ is accepted it can be concluded that there is a difference in the increase in student learning outcomes that are taught using mobile learning media with PowerPoint media integrated PBL learning models on chemical equilibrium learning.

\section{DISCUSSIONS}

The product produced from this developing research is a application andoid. It is created and designed by the researchers, with the aim of being used as a tool for teachers to transfer the lesson materials and also as a source of independent learning which can be used by students outside of school at any time.

Wireless and mobile technology development has grown rapidly in recent years [11][12]. This technology is becoming more and more sophisticated, but at a cheaper price. The use of a smartphone as a mobile learning tool in schools has become controversial among teachers. On one hand, some teachers disagree because it would interfere the learning process in the classroom; on the other hand, some teachers saw a lot of potential that needs to be used in learning [13][14][15]. But, todays educators realize that the digital mobile technology has provided new opportunities for the availability of new and different forms of learning; including the relationship between teachers, learners and learning objects [16]. Given the current technological developments 
and the latest results of research on learning motivation, appreciation toward media facilitated learning and learning resources varied [15][17]. Learning is much easier and diverse. The use of mobile instruments are proven to encourage student motivation and to support their own learning activities [11][14].

Increased of the conceptual skills of $\mathrm{N}$-gain students using this mobile learning media is also supported by research presented by Muqarrobin [19], the average percentage of responses to student learning achievement is $0.95 \%$. Based on this data it can be concluded that (1) the Android-based physics e-book learning media is declared fit for use, (2) there is significant difference in learning achievement between a class using the said learning media and a class using the learning media usually used at school, (3) there is no significant difference in learners' response to the learning ease that they get when using the Android-based physics e-book learning media compared to that when using the learning media from the school, and (4) learning ease does not fully influence learners' learning achievement.

\section{CONCLUSION}

Based on data analysis and discussion of the results of the research conducted, the conclusions can be drawn as follows:

1. The developed mobile learning media has a very feasible category so it is suitable for use in chemistry learning.

2. There is a difference in the increase in student learning outcomes (N-gain) of topic of chemical equilibrium using mobile learning media which has been developed with Power Point media obtained

\section{ACKNOWLEDGMENT}

The author would like to acknowledgment head of chemistry department and dean of the faculty of mathematics and natural sciences Universitas Negeri Medan.

\section{REFERENCES}

[1] . Anitah, Sri. 2009. Technological Learning. Surakarta: Yuma Library.

[2] . O. Hamalik, "Teaching and learning process", Jakarta, Sinar Grafika, 2007.

[3] . Rasim and W. Setiawan, "Development of Instructional Devices for Information Technology and Technology-Based Learning", Jurnal Pendidikan TIK, vol 1(2), pp. 1-10, 2008.

[4]. St Mulyanta dan Marlon Leong. 2009. Tutorial membangun multimedia interaktif Media Pembelajaran. Universitas Atma Jaya. Yogyakarta.

[5] . Djamarah. (2008). Strategi Belajar Mengajar. Rineka Cipta. Jakarta.

[6] . Manalu, R., Silaban, S., Hutabarat, W "The Development of Teaching Materials: Stoichiometric Integrated Multimedia Easy Sketch" Advances in Social Science, Education and Humanities Research, volume 200. 2018

[7] . Catch The Erlenmeyer pada Materi Tatanama Senyawa Kimia untuk Kelas X SMA. Prosiding Seminar Nasional Kimia dan Pembelajarannya (hal. B-135 - B-143). Surabaya: Jurusan Kimia FMIPA Universitas Negeri Surabaya, 2016
[8] . Sadiman, Arief S, Rahardjo, \& Haryono, Anung. Media Pendidikan: Pengertian, Pengembangan dan Pemanfaatan. Jakarta: PT. Raja Grafindo Persada, 2014

[9]. Mehdipour Yousef \& Zerehkafi Hamideh. 2013. Mobile Learning for Education: Benefits and Challenges International Journal of Computational Engineering Research (IJCER) Vol: 37 Issue: 6.

[10] . D. Priyanto, "Understand Data Statistical Analysis with SPSS", Yogyakarta: Mediakom, 2010

[11] . Fajrina, W, Nurfajriani, Simorangkir, M. "Developing Interactive Computer Based Learning Media of Lectora Inspire to Enhance Conceptual Skills of Senior High Schools Students", Advances in Social Science, Education and Humanities Research, volume 200. 2018

[12]. Alqahtani, M., \& Mohammad, H. (2015). Mobile Applications' Impact on Student Performance and Satisfaction. TOJET: The Turkish Online Journal of Educational Technology, Vol. 14 Issue 4 102-112.

[13]. Sulisworo, D. (2014). Concetual Model Identification of Persona Learning Environment. Innovation and Development in Teaching and Learning (hal. 37-41). Perak, Malaysia: UMM.

[14]. Sulisworo, D. (2013). The Paradox on IT Literacy and Science's Learning Achievement in Secondary School. Internasional Journal of Evaluation and Research in Education, Vol 2 No. 4 , 149-152.

[15]. Tal, H. M., \& Gross, M. (2014). Teaching Sustainability via Smartphone-Enhanced Experiential Learning in a Botanical Garden. International Journal of Interactive Mobile Technology, Vol. 8, Issue 1,1015 .

[16] Mohammad, H., Fayyoumi, A., \& AlShathry, O. (2015). Do We Have to Prohibit the Use of Mobile Phones in Classrooms? International Journal of Interactive Mobile Technology, Vol. 9, Issue 2, 54-57.

[17]. Babiker, M. E. (2015). For Effective Use of Multimedia in Education, Teachers Must Develop their Own Educational Multimedia Applications. TOJET: The Turkish Online Journal of Educational Technology, Vol. 14 Issue 4 , 62-68.

[18] . Kirmizi, Ö. (2014). A Study on the Predictors of Success and Satisfaction in an Online Higher Education Program in Turkey. International Journal of Education,Vol. 6, No. 4, 26-45.

[19]. Thinley, P., Reye, J., \& Geva, S. (2014). Tablets (iPad) for MLearning in the Context of Social Constructivism to Institute an Effective Learning Environment. International Journal of Interactive Mobile Technology; Vol. 8, Issue 1, 16-20.

[20]. Muqarrobin. T, Kuswanto. H, "Development of an android-based physics e-book to ease students' physics learning And its influence on their learning achievement", American Journal of Engineering Research (AJER), Volume-5, Issue-10, pp-223-229. 